University for Business and Technology in Kosovo

UBT Knowledge Center

UBT International Conference

2014 UBT International Conference

Nov 7th, 5:15 PM - 5:30 PM

\title{
Research of the problems faced by construction companies in Kosovo
}

\author{
Muhamet Ahmeti \\ Vienna University of Technology, muhametahmeti@gmail.com \\ Mimoza Sylejmani \\ University for Business and Technology, mimoza.sylejmani@ubt-uni.net
}

Follow this and additional works at: https://knowledgecenter.ubt-uni.net/conference

Part of the Architecture Commons

\section{Recommended Citation}

Ahmeti, Muhamet and Sylejmani, Mimoza, "Research of the problems faced by construction companies in Kosovo" (2014). UBT International Conference. 9.

https://knowledgecenter.ubt-uni.net/conference/2014/all-events/9

This Event is brought to you for free and open access by the Publication and Journals at UBT Knowledge Center. It has been accepted for inclusion in UBT International Conference by an authorized administrator of UBT Knowledge Center. For more information, please contact knowledge.center@ubt-uni.net. 


\title{
Research of the problems faced by construction companies in Kosovo
}

\author{
Muhamet Ahmeti ${ }^{1}$, Mimoza Sylejmani ${ }^{2}$ \\ ${ }^{1}$ Vienna University of Technology, Vienna; Austria \\ ${ }^{12}$ University for Business and Technology, \\ Faculty of Architecture and Spatial Planning, Prishtina, Kosovo \\ $\underline{{ }^{1} \text { muhametahmeti@gmail.com }}{ }^{1},{ }^{2}$ mimoza.sylejmani@ubt-uni.net ${ }^{2}$
}

\begin{abstract}
This paper presents the research of several construction companies that deal with building design and execution. The questionnaire was conducted with about 140 companies which are interviewed, the case identified the main problems faced by construction companies design the execution today in Kosovo. This paper has a special significance since it identifies the main problems faced by companies, the main factors affecting the delays and problems during the execution of the works, identifies and gives a clear overview of the different options that companies operating in Kosovo to deal with mega projects such as infrastructure as well as in construction. This paper enables companies but also various institutions, as well as various ministries that good with these matters in order to propose measures that should be taken in the construction, execution and design companies in Kosovo, In this paper we provide and implication that how to act in case of Kosovo regarding this problem, when according to the statistical analysis and logistics aspects of mechanization regard to Kosovo is very good, and have a very large number of different means of mechanization which has various companies in Kosovo, mechanization percentage is much less exploited, pribadong that if their organization becomes involved with a grouping or consortium that benefit the construction design and execution will be able to realize mega infrastructure and constructions diferent projects .In this work is proposed various solutions to eliminate very large delays in execution of works, as well as beter coordination between different companies to implement mega projects in infrastructure and different mega building objekts.
\end{abstract}

Key words: Companies, Kosovo, construction, projects, mechanization.

\section{Introduction}

This paper deals with Construction capacity building and road project in Kosovo. The construction sector is one of the key economic sectors and is the main force motivating the Kosovo national economy. the construction sector has witnessed noticeable expansion and activities.

Therefore, the construction sector has occupied a very important position relative to the rest of the economy, attracting investments and creating new jobs .

This is a large proportion that positively affect various other economic, social, educational and vocational sectors and Kosovo institutions.

In spite of the high importance of construction sector in Kosovo, the industry suffers from a number of problems that affect time, cost and quality performances.

Conducted a this study to investigate the time delay in road construction projects and other mega building and road projects ( financed from government's of Kosovo, and other project financed from EU ) in Kosovo. In all this projects suffer from time overrun and that $100 \%$ of the projects experienced delays between $40 \%$ and $200 \%$ of the contracted duration.

Therefore, attention should be paid to this important sector in order to identify its main challenges and control them.

This study aims at identifying the common risks affecting time overruns in road construction projects in the Kosovo and risks from the contractors' point of view. 
It is hoped that the findings of this study will provide a solid overview and guide efforts to enhance the performance of the construction industry.

\section{Research methodology}

18 factors that may cause the delay of road projects and building construction are defined by this review of the literature. Factors are presented in a form of questionnaire.

Each section also has questions factors that characterize this part of the factors associated with general information about the "respondents companies and contractors, and supervisors to work problems.

Part II contains the list of identified causes of delay in projects road construction and cause the company's capacity to complete mega projects .

Survey regarding the problems faced by the Company during the construction time when the construction works on the roads or is mega projects were conducted by the students from UBT who have conducted and interviews of around 120 different construction companies which have experience in constructions works from 25 to 10 years .

Also the capacity of the companies that were interviewed for the number of employed workers has been from 50 to 1000 employees.

\subsection{Build the right types of capacities of buildings company}

Another challenge for effective capacity building is getting clear on what sorts of competencies, awareness, and skills need to be built.

The classification of two general types of capacities, "functional" and "technical," provides a useful framework for thinking about capacity building A third category, "behavioral," relates to awareness and attitudes.

- FUNCTIONAL CAPACITIES are "crosscutting" capacities that are relevant across various levels and are not associated with one particular sector or theme.

They are the management capacities needed to formulate, implement, and review strategies, programs, and projects. Since they focus on "getting things done," they are of key importance for any successful capacity development. These capacities are the ones that companies are most likely to target as part of CI.

- TECHNICAL CAPACITIES are those associated with particular areas of expertise and practice in specific thematic areas or sectors.

For the technical skills may closely relate to a sector or program focus, such as microfinance, small business training, education, health, or agriculture. Technical capacities tend to be acquired through more formalized instruction, study, and practical training. Because this tends to be a more specialized set of skills, the target audience is generally much narrower.

- CAPACITIES have to do with cultural shifts and changes in attitude.

An important component of capacity building, especially in a multi-stakeholder context, is raising awareness in order to affect changes in the attitudes, practices, and behaviors of individuals, groups, and organizations. These changes include partnering, building alliances, and interacting in new or different ways. Behavioral capacity building can also prompt changes in strategy direction, policies, and institutional culture. 
2.2 SWOT ANALYSIS- about building capacities for building company's - case studies

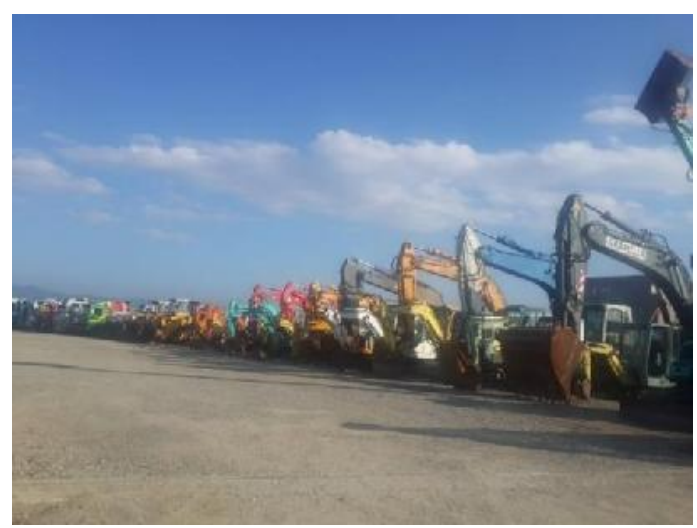

Fig 1. ( 05.11.2014)

In tables identifying the companies that are doing work in different segment of the road Prishtina Mitrovica, where the observed period of work performed
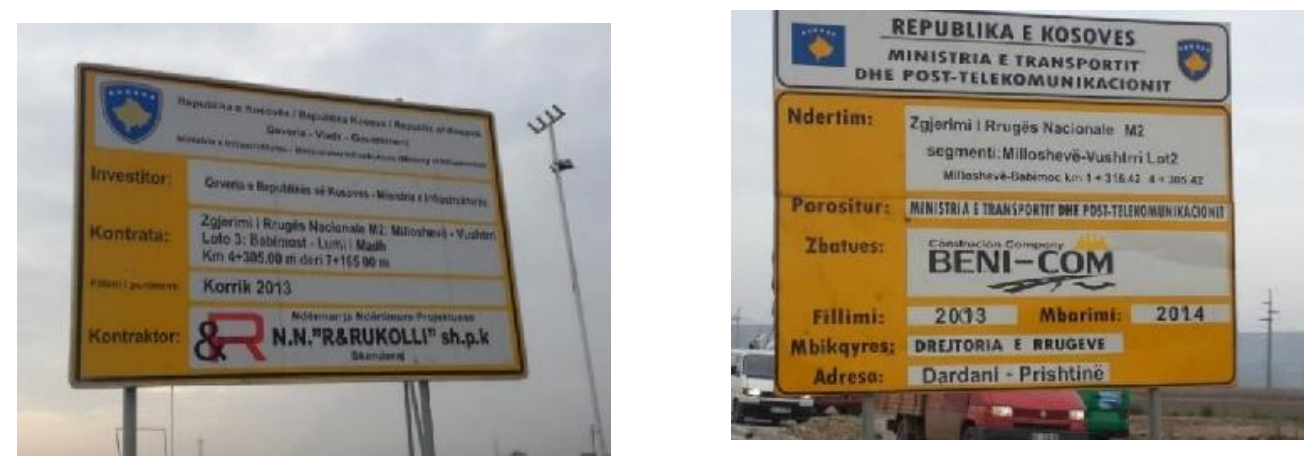

Fig 2 ( 06.11.2014)

Deadline for completion of the works is at the end of 2014 or has expired and the situation in the field tells us that these works can not be completed at least 6 months.
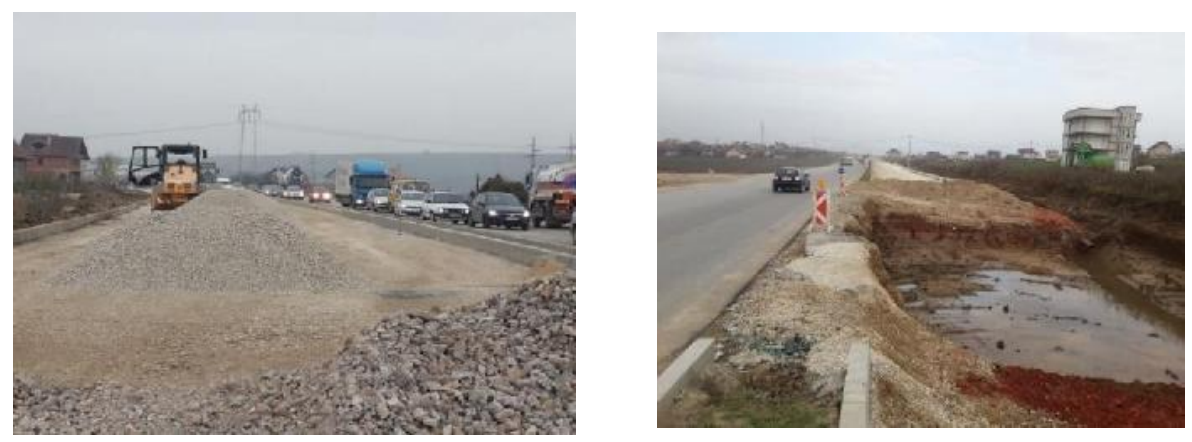

Fig 3. The situation in the field (06.11.2014) 
The situation in the proceedings dated 11.06.2014 segments of road Pristina - Mitrovica
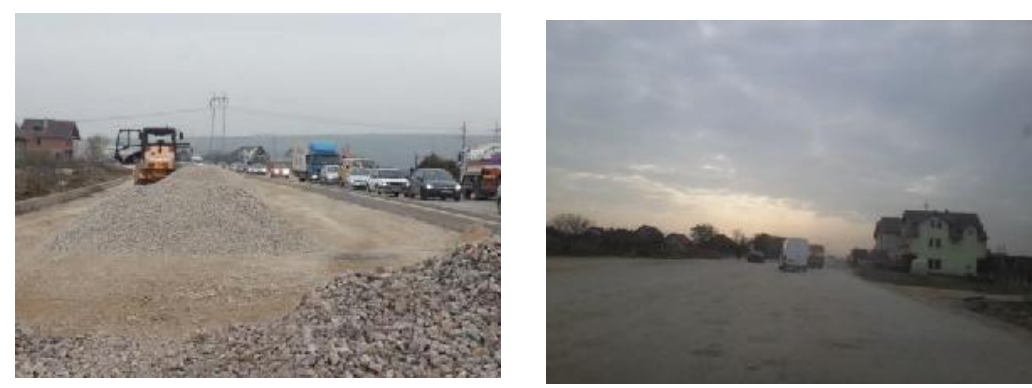

Fig 4. The situation in the field ( 06.11.2014)

\section{SWOT ANALYSIS}

Therefore the aim of part is to obtain the factors that are impacting on these delays.

When it is known that the number of workers in Kosovo is very large, where this factor is not a cause of delays during visits is found that the number of mechanization necessary for execution of works sufficient friend, so where is the problem. Where a known fact that companies who carry out work in Kosovo motorway ( Bechtel Enka ) $90 \%$ of the employees are local, so a large percentage of the local mechanism he used while performing dynamic plan that works respected, also have times when the work is done ahead of schedule plan prescribed by dynamic and contracted.

\section{Questions were submitted to representatives of the companies during the survey}

1. How much are you satisfied with the cooperation with the investors and constructions company

2. How satisfied are you with the professional association of the supervisory body:

3. Sa are satisfied with the cooperation with the designers,

4. Main problem's encounter during the execution of the works are,

5. How do you think you should be on the site visits of the supervisory body.

6. As is now the supervisor visits

7. How regular are the documentation on the site, logbook, book construction and other documentation needed for the site.

8. Do you think regular visits supervisory body affects the dynamic plan of work performed and to eliminate possible errors in the project?

9. Do you think that regular monitoring by the investor affects the dynamic plan of work performed?

10. Do you think Kosovo companies have professional human resources and logistical support for the implementation of major construction projects and infrastructure:

11. Does the professional capacity of companies in the implementation of large infrastructure projects, or affect the quality of works completed

12. Do you think Kosovo companies dealing with road infrastructure that can be competitive in the regional and global market.

13. Where do you get the raw material for the realization of infrastructure projects

14. If you get raw material abroad or have a delay in supply and affect the delays in delaying the implementation of infrastructure projects in Kosovo.

15. If Kosovo will be investment in rail traffic has a local company that will be able to realize these projects.

16. What are the most common obstacles that slow you work in the realization of projects

17. Who can positively affect the elimination of barriers that have construction companies in Kosovo? 
1. How much are you satisfied with the cooperation with the investor and other constructions company?

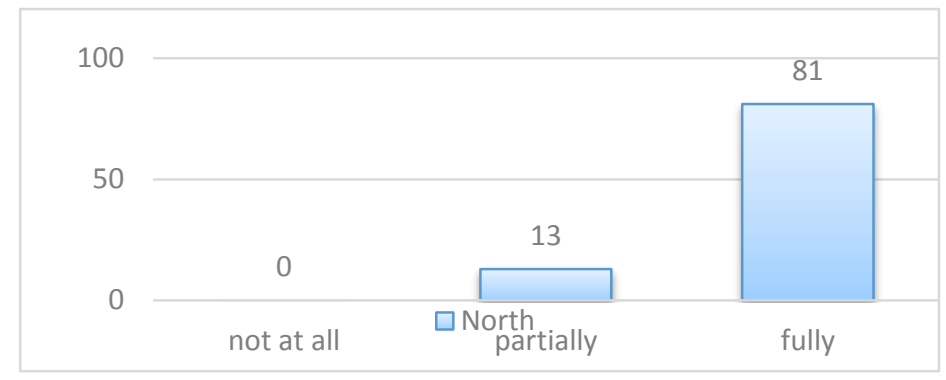

2. Are you satisfied with the professional association of the supervisory body:

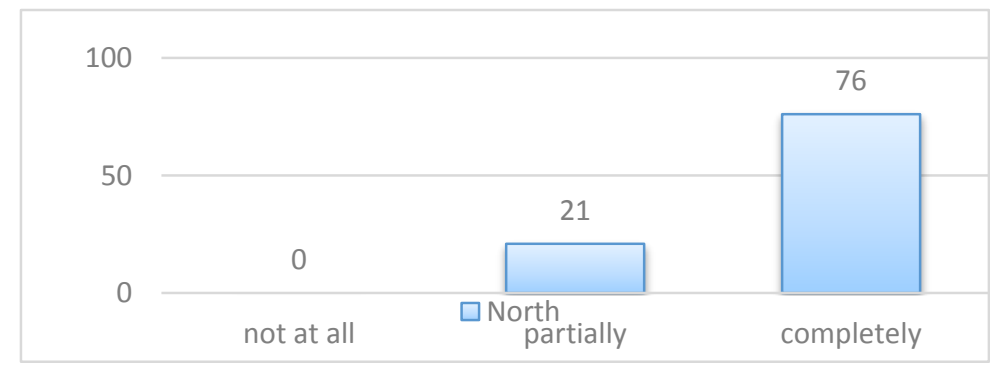

3. Are satisfied with the cooperation with the design projects :

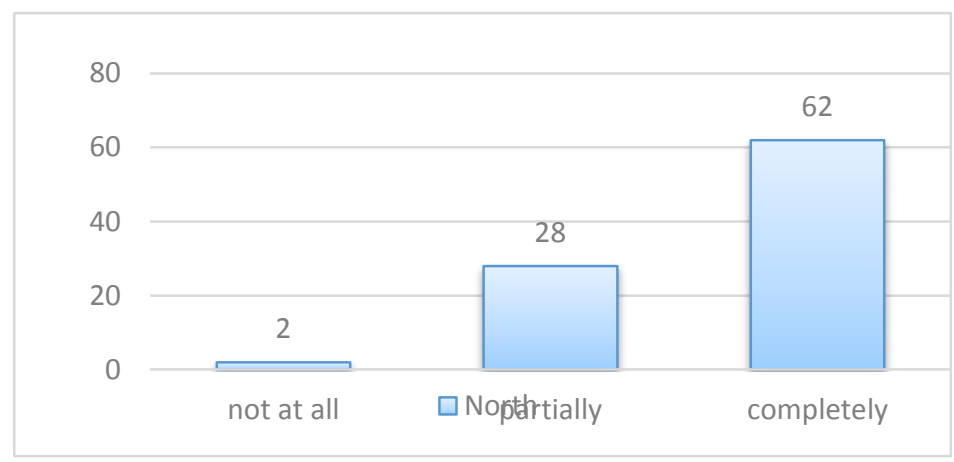


4. Main prblem's encounter during the execution of the works are :

1.property problems

2. payment by the investor for the executed wo

3. Inadequate capacity for completion of works

4. Errors in the main project

5.bureaucracy and administrative problems

burdens by the investor or various municip

oversight

4. Main problem's ( of constructions company ) encounter during the execution of the works are

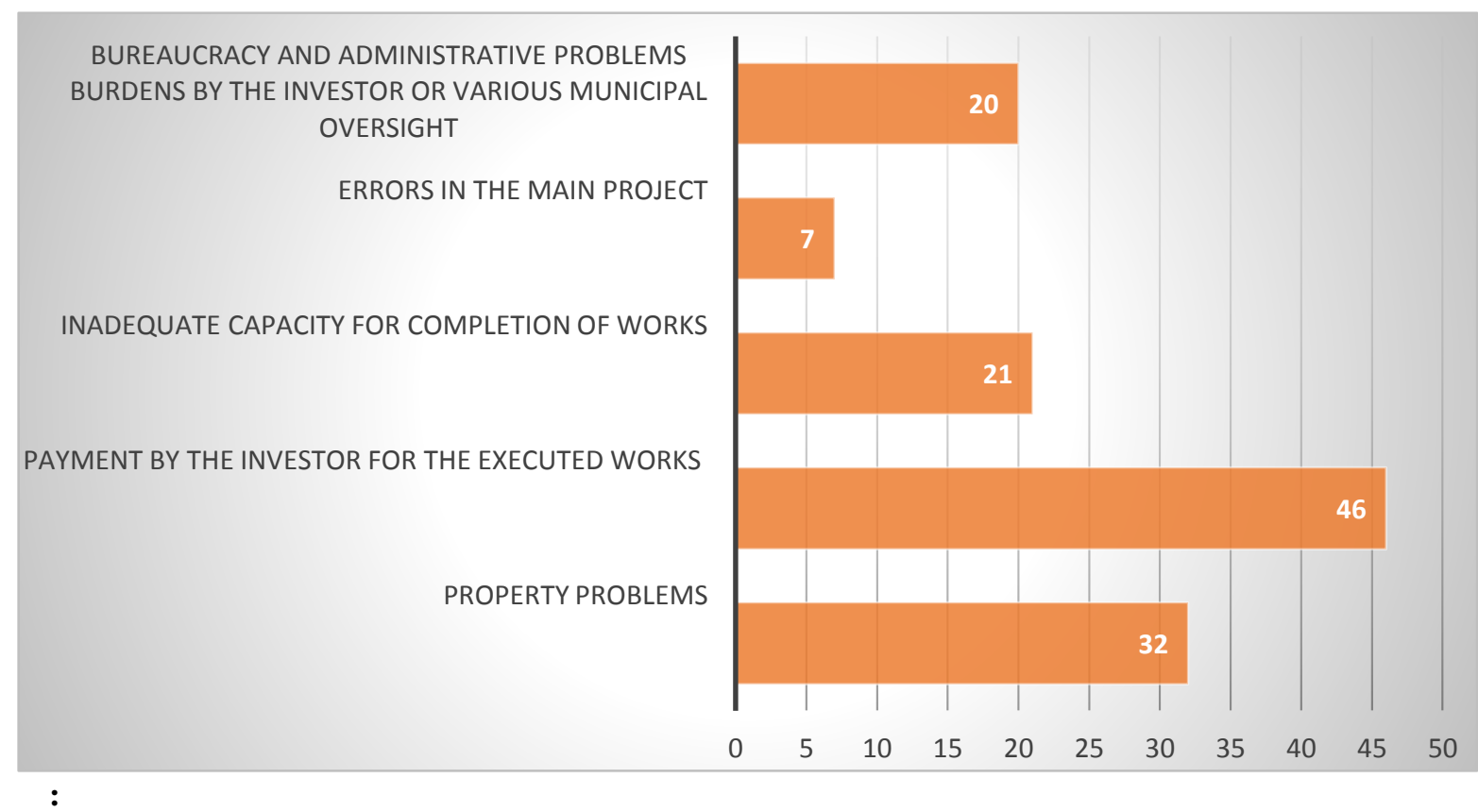

5. How do you think you should be on the site visits of the supervisory body. 
daily visits

2 weekly visits

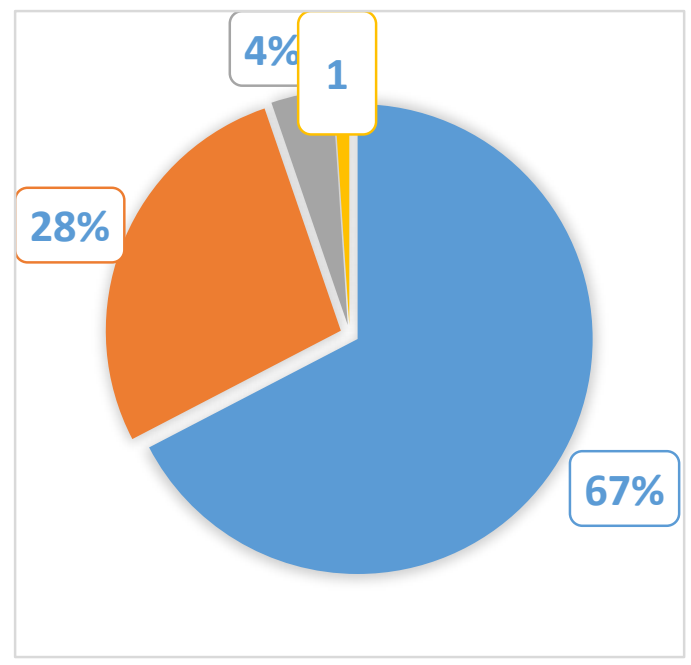

weekly visits.

Or proposal

5. How do you think you should be on the site visits of the supervisory body.

daily visits

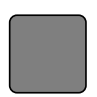

$\square$

2 weekly visits

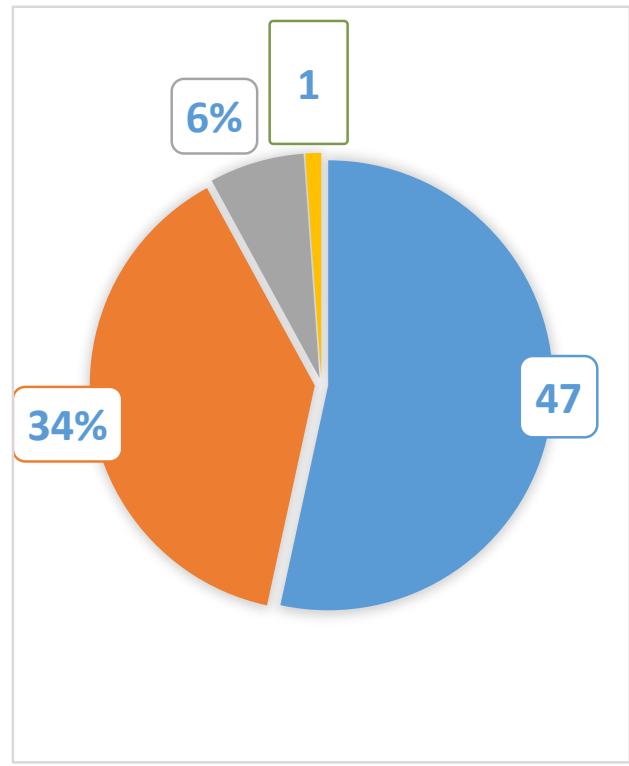

weekly visits.

Or proposal

7. At which level is now the technical documentation on the site : 


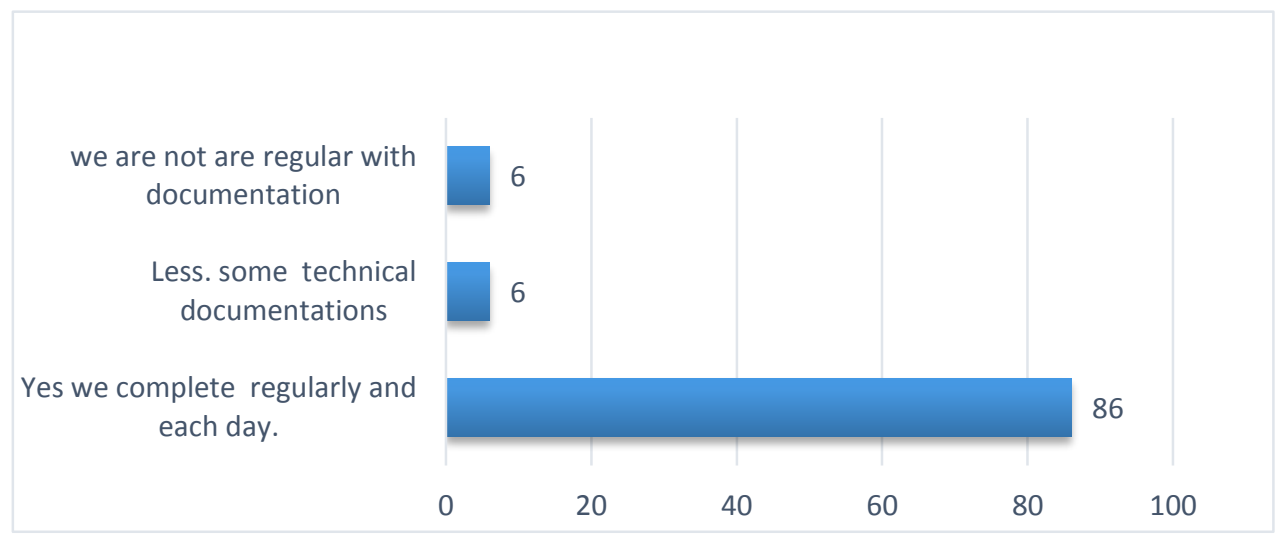

8. Do you think regular visits supervisory body affects the dynamic plan of work performed and to eliminate possible errors in the project.

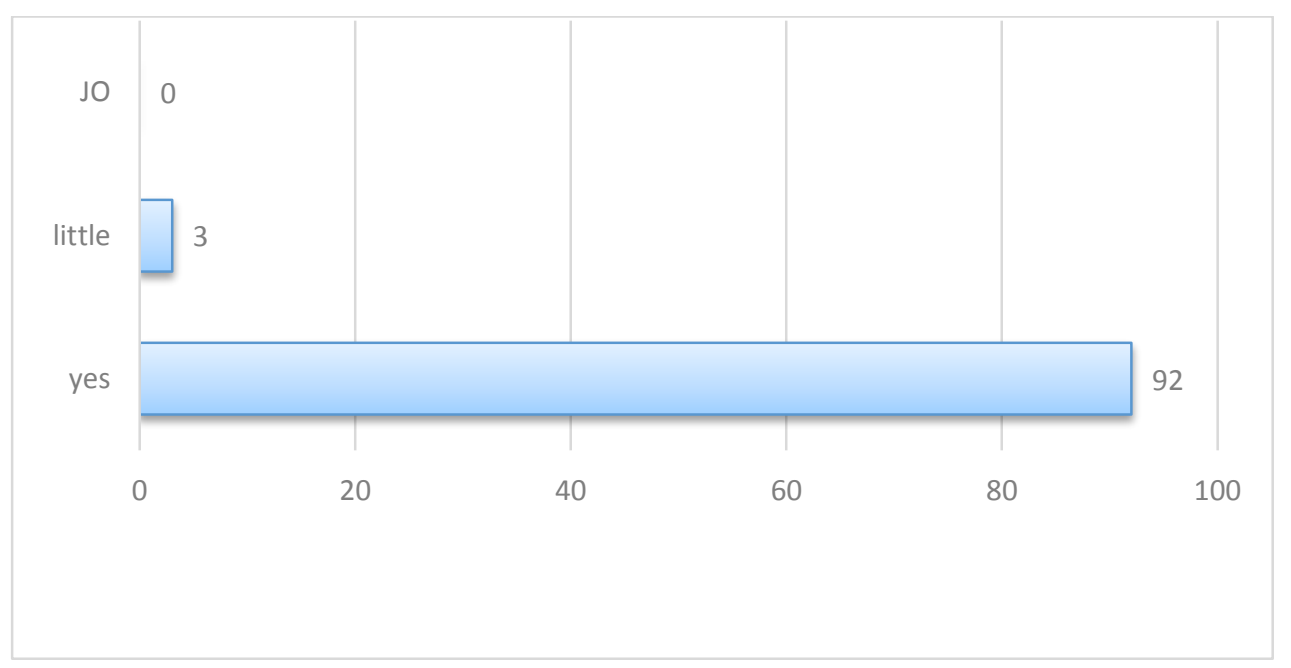


9. Do you think that regular monitoring by the investor affects the dynamic plan of work performed.

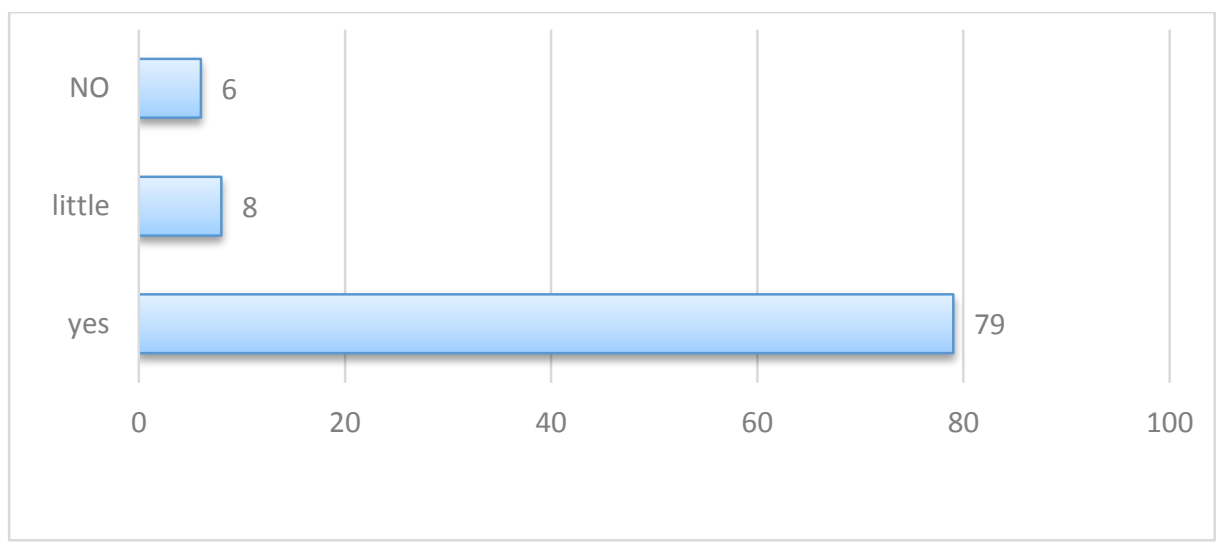

10. Do you think Kosovo companies have professional human resources and logistical support for the implementation of major construction projects and infrastructure:

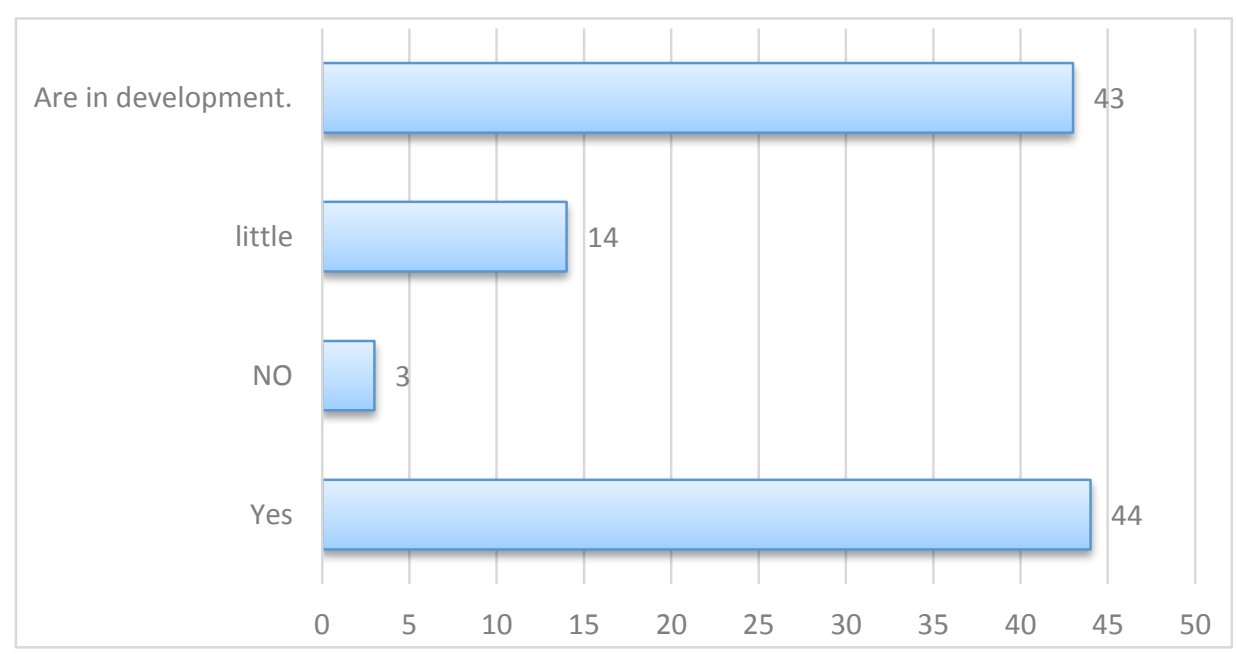


11. Does the professional capacity of companies in the implementation of large infrastructure projects, or affect the quality of works completed :

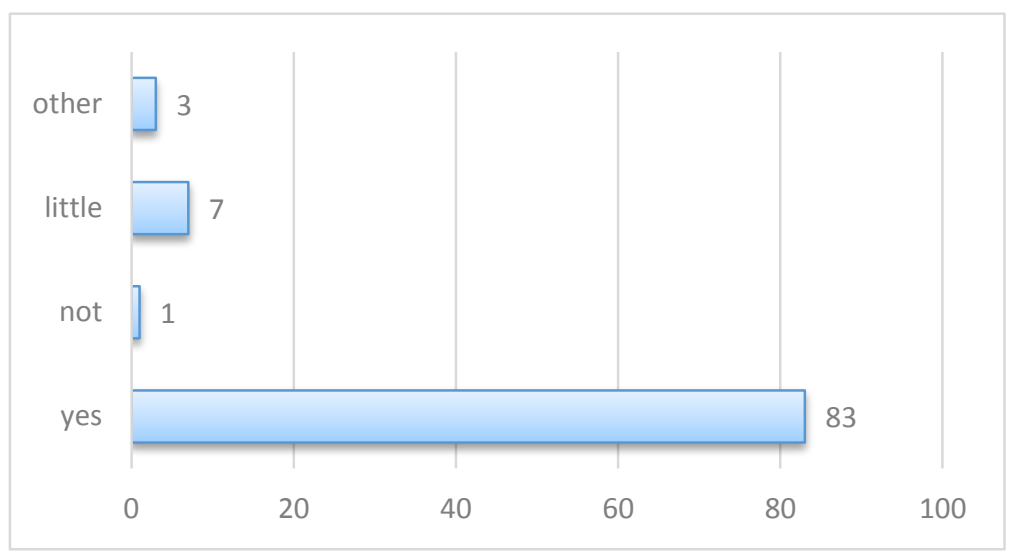

12. Do you think Kosovo companies dealing with road infrastructure that can be competitive in the regional and global market.

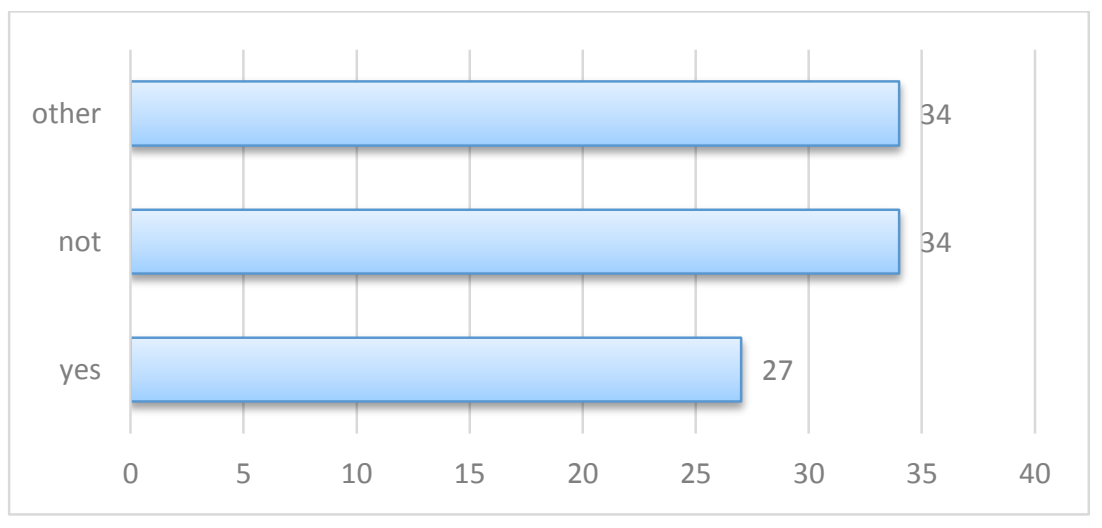

13. Where do you get the raw material for the realization of infrastructure projects

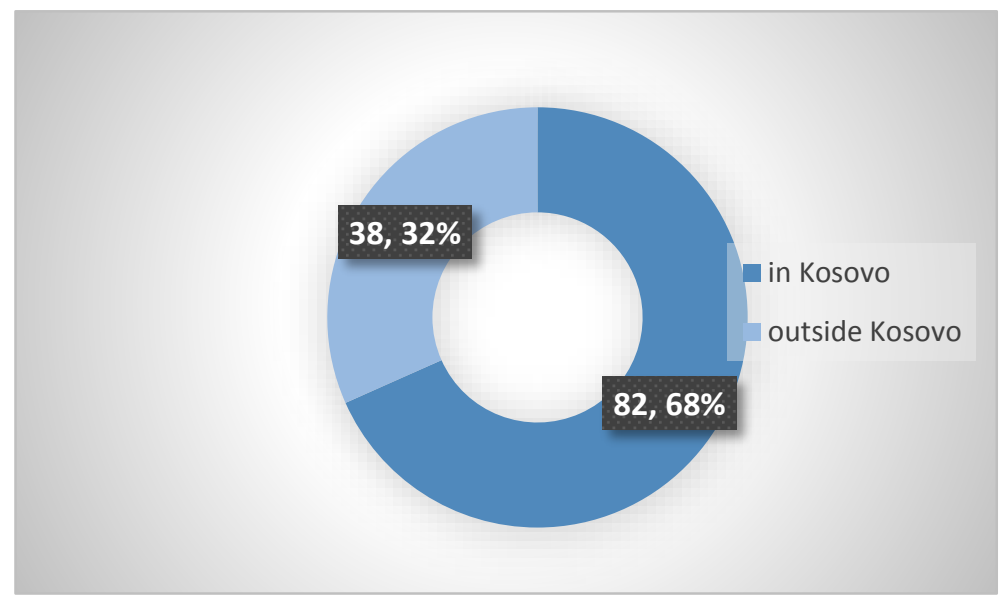


14. If you get raw material abroad or have a delay in supply and affect the delays in delaying the implementation of infrastructure projects in Kosovo.

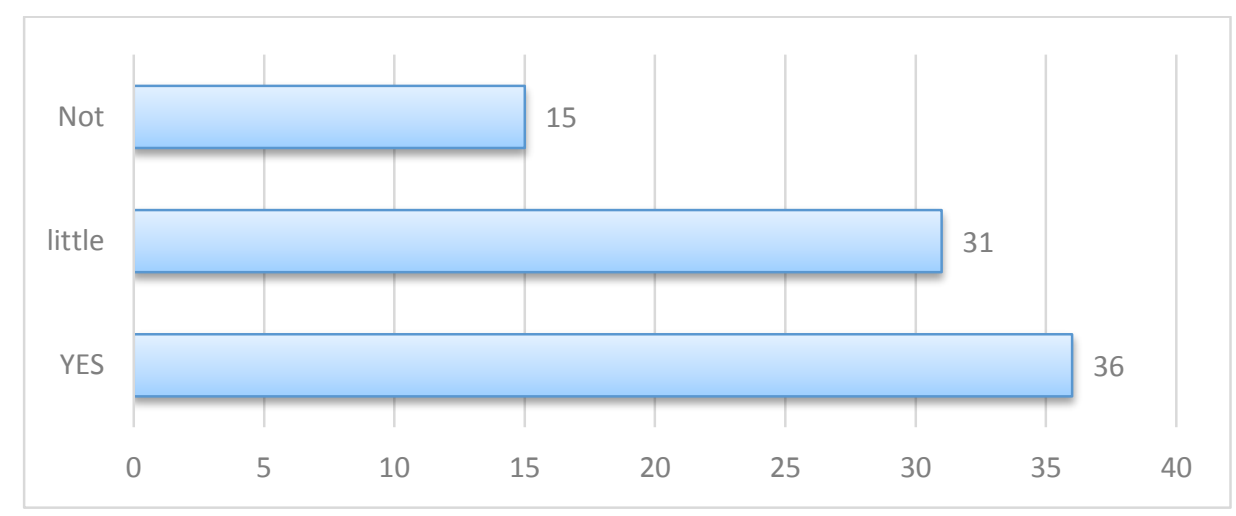

15. What you wil have an offer to transport raw materials through rail traffic:

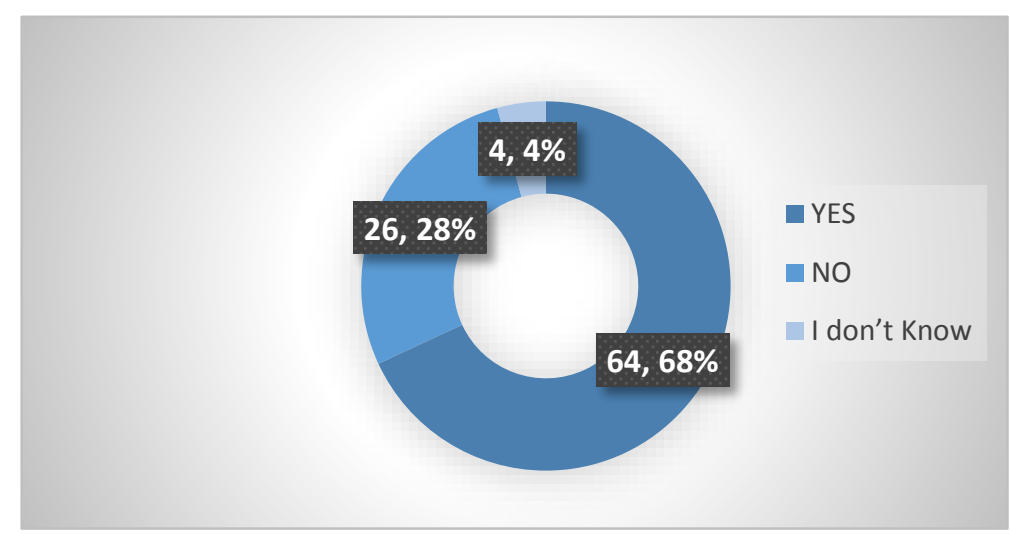

16. What are the most common obstacles that slow you work in the realization of projects.

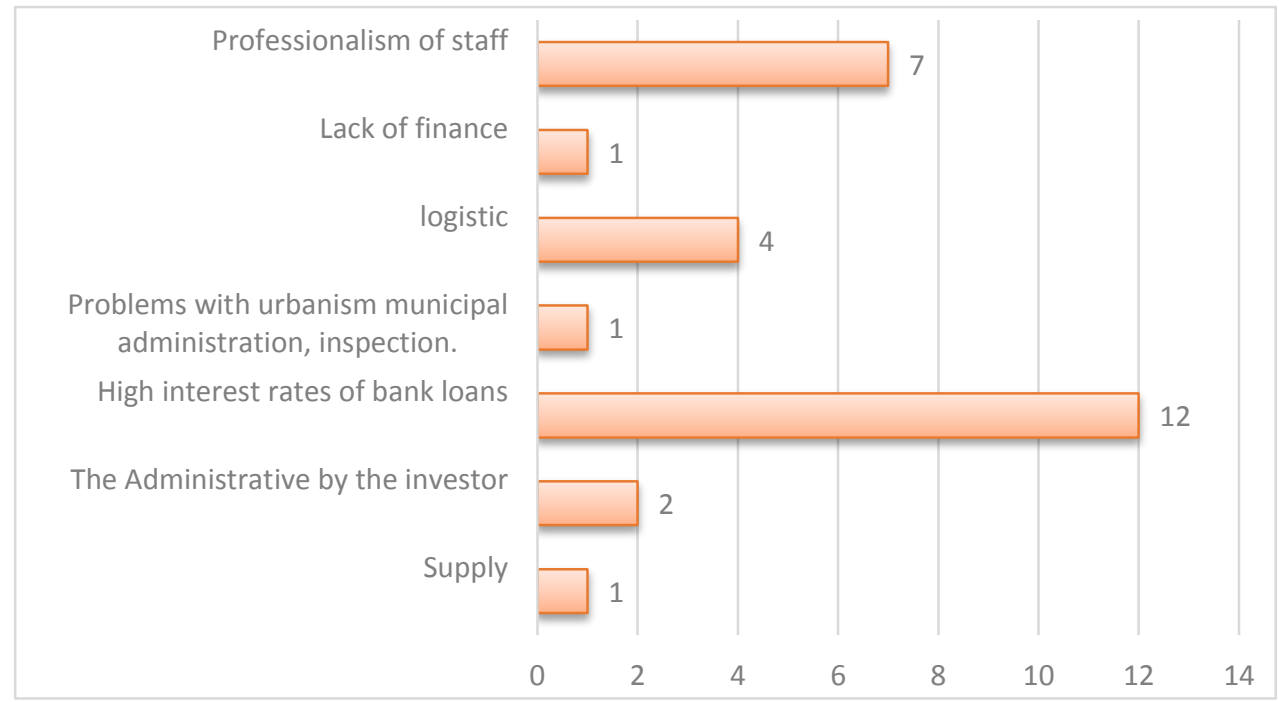


17. Who can positively affect the elimination of barriers that have construction companies in Kosovo.

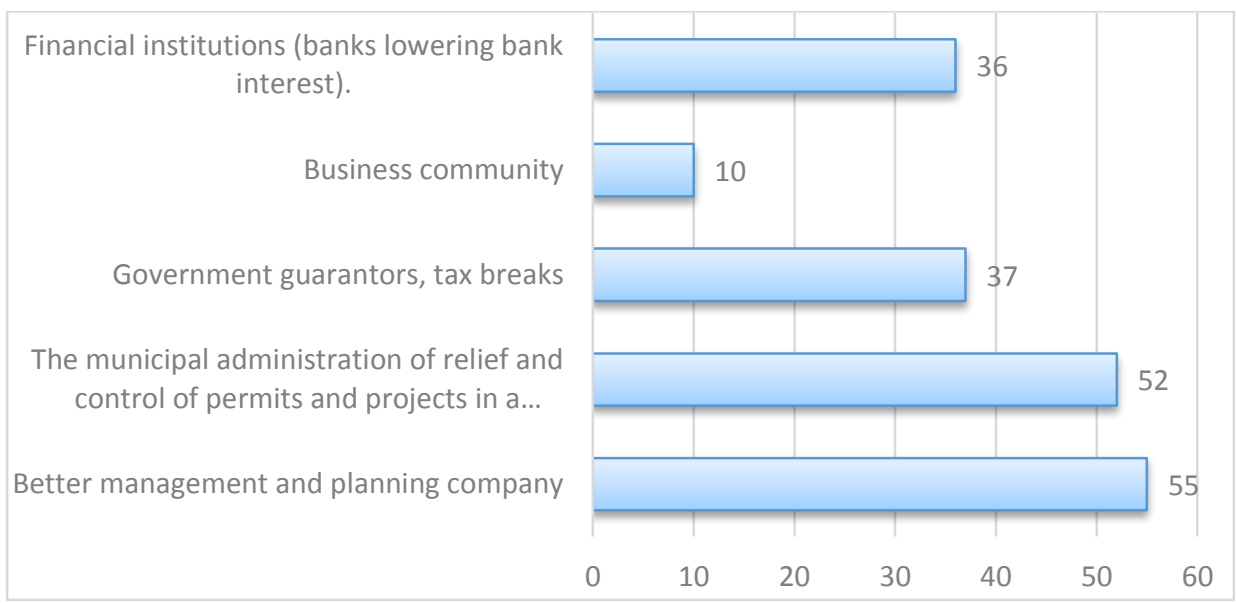

Main challenges

1. Poor image / reputation

2. Late payment

3. Competitive tendering procedures

4. Over-specification (i.e. over designed)

5. Reliance on the traditional procurement route

6. Cost overruns

7. Poor quality / workmanship

8. Late completion

9. Changes of design during construction

10. Time constraints and/or accelerated completion

11. Low productivity

12. Absenteeism of labour

13. Excessive overtime

14. Cowboy builders

15. Low plant utilization

16. Fragmentation

17. Wastage

18. Inexperienced management and supervision

\section{Results and discussion}

In this study, are presented 18 factors that might cause time delays in road construction projects in the Kosovo .

These factors were classified into groups: project, managerial, consultant, financial, external, and construction items. 
Number of mechanism, you now possess in Kosovo companies, which have found that the number of the mechanism is sufficient to realize the major projects.

\section{Conclusion}

Factors that affect the timing of work performed in road construction projects in Kosovo contractors. The most important factors are: delays in payment by the investor, unresolved problems proprietary, financial status of contractors, poor communication between construction parties, lack of equipment efficiency and high competition in bids (offers low prices Companies unprofessional), poor supervision. as well as the government can reduce these problems to the benefit of all parties to construction. Affairs are: delays in payment by investors, issues of ownership, financial condition contractors, poor communication between the parties to the construction and equipment efficiency low.

Also worth mentioning that in Kosovo there are companies which can be performs work which require commitment of manpower and much greater mechanization

The findings of this study have identified critical factors common between this study and studies investigated, namely: the financial status of contractors, property fix problems, late payments from investors and poor communication between construction parties. Contractors also have views on the factors that were not previously identified as low-efficiency equipment, high bids races.

Recommendations:

- To realize major infrastructure works and other major projects that companies need each other to reach their union in terms of manpower, as well as the mechanism should be established good coordination with the Government of Kosovo institutions and other investors.

- Process the start of the works should be preceded by the choice of all the problems that proprietary projects or related projects to be realized.

- Should establish a special body which would also searched verified all the data of companies that compete on various projects, this body should be investigated real situation of competing companies as financially, in terms of strength and mechanism, you analyzed and verified projects realized the contracting company,

- I interviewed managerial and professional staff, and after selecting the pancreas based on the recommendations of this body, and authorizing the company proposed to be taken with supervision but also with consultants that will give the company winning also be searched and payment problems helped to finished works, realized in order to work within the time prescribed, to give recommendations but in case of serious problems in the execution of works contract demanded interruption for companies that performs work. 